\title{
Student Worksheets With The Spldv Calc Application To Improve Creative Thinking Abilities
}

\author{
Ika Krisdiana ${ }^{1}$, Reza Kusuma Setyansah ${ }^{2}$, Indah Aditiya Pratiwi ${ }^{3}$ \\ 1,2,3 Mathematics Education Study Program, Universitas PGRI Madiun, Madiun \\ e-mail: ikakrisdiana.mathedu@unipma.ac.id¹
}

\begin{abstract}
The purpose of this development research is to develop math worksheets using the SPLDV Calc application and to find out how to improve students' creative thinking skills with a 4D development model that is modified into 3D. The stages of this research development consist of: define, design, and develop. The results of this product development are (1) fulfilling the validity criteria based on the final validation percentage of $87 \%$ for LKS and $89 \%$ for the SPLDV Calc application; (2) meet the effectiveness criteria based on the results of student learning completeness to achieve classical mastery with a percentage of $86 \%$; (3) meeting the criteria for practicality with a student response questionnaire percentage of $85 \%$ giving a positive response. The developed worksheets can improve students' creative thinking skills, it is indicated that there is an increase in the pretest to posttest scores from the $\mathrm{N}$-Gain test score of 0.73 with high interpretation, so that the student worksheets can be used by students in learning This shows that android-based worksheets make it easier to learn mathematics.
\end{abstract}

Keywords: Mathematics, SPLDV Calc, Creative Thinking

\section{Introduction}

Facing 21 st century learning and the 4.0 industrial revolution required creative thinking skills. Creative thinking skills is implemented in various learning content in education, one of which is solving math problems (Siswono, 2005; Widodo, 2018). In addition to learning and innovation skills known as 4C which include communication, collaboration, critical thinking and problem solving, creativity and innovation (Erozkan, 2013; Farida, 2009; Murti, 2015; Wang and Chiew , 2010). Efforts to assist students in constructing an understanding of a concept require creative thinking skills by linking new knowledge and old knowledge gained in school. Indicators of creative thinking include fluency, flexibility (flexibility), and novelty (Siswono, 2018).

One of the ways to think creatively in students is by using the development of Student Worksheets (LKS) (Krisdiana, et al, 2019). The lack of suitability of student teaching materials in the form of student worksheets with their fields of expertise results in teachers often repeating material and allowing students to be less able to improve creative thinking skills. The worksheets contain short material and questions that must be done by students, although student worksheets can contribute to student learning but they still look less effective based on the low level of student activity and have not shown their creative thinking skills (Elfiani, 2017; Putri, 2015). This underlies researchers to develop math worksheets with the SPLDV Calc application, where students only obtain material theoretically during learning, thus making students less interested in understanding the material as a whole in line with the development of the automotive world.

The use of suitable teaching materials in the form of worksheets aims to make students more competent. LKS is teaching material in the form of sheets containing assignments that students must do with the aim of activating students during the activity process, helping students develop concepts, training students to find and develop process skills (Lestari \& Yudhanegara, 2015). As a complement / means of supporting the implementation of the Learning Plans, LKS aims to lead students to produce original works (original) and promote student involvement in learning as expressed by (Majid \& Rochman, 2014). The worksheets used by students so far are still conventional in the form of books containing material summaries and practice questions that have not applied ICT. Even though the use of student

\footnotetext{
${ }^{\star}$ Corresponding author.
}

Received 19 August 2019; Accepted 18 September 2020; Available online 01 December 2020 (c) 2020 JPI. All Rights Reserved 
worksheets has a positive impact on users, including improving students 'reasoning abilities according to (Fitriani et al, 2017) and can improve students' critical thinking skills (Lestari \& Darsono, 2018). With the LKS developed using the SPLDV Calc application, it is hoped that students will understand the concept, be able to solve problems related to natural phenomena, and improve creative, innovative thinking and be able to correlate various STEM disciplines with real problems.

STEM education is an approach in science, technology, engineering and mathematics education integrated with an educational process that focuses on problem solving and is able to develop products, processes and systems in real life and everyday life (Devi et al, 2018). The learning model used is Project Based Learning (PjBL) STEM Laboy Rush which is a model to be implemented in the 2013 curriculum by emphasizing four scientific fields (Devi et al, 2018). Integrated STEM learning has the potential to prepare a competitive future workforce with 21st-century skills, with creative thinking that can help students gain in-depth knowledge of the topics they are studying (Marsono \& Khasanah, 2019).

This study aims to develop math worksheets. with the SPDV Calc application and to analyze the impact of these implementation toward students' creative thinking skills.

\section{Method}

The research method used is a research and development method that aims to develop a new product or improve an existing product, which can be accounted for (Creswell, 2012; Sukmadinata, 2015; Widodo, 2017).

The development of teaching materials such as worksheets can use the 4D development model which consists of 4 stages, namely define, design, develop, and dissemate (Mulyatiningsih, 2013). The development model used in this development research adapts the 4D model that is modified into 3D referring to the learning model developed by Thiagarajan (Sani \& Manurung, 2018). This research was conducted with 30 students as research subjects.

The define stage includes front end analysis, concept analysis, and analysis of learning objectives. The design stage includes the preparation of instruments and the initial design of the product being developed. While the develop stage consists of expert validation. In the analysis of the validity of math worksheets with the SPLDV Calc application using the Likert scale proposed by (Widoyoko, 2013) which is very good, good, not good, not good, and very bad. From the total score obtained, it is percentage to determine the validity level of the product being developed. The formula used to process validation data is adapting from (Akbar, 2013) as follows:

$$
\mathrm{V}=\frac{\mathrm{TSe}}{\mathrm{TSh}} \times 100 \%
$$

Information:

$\mathrm{V}=$ Percentage of validity

TSe $=$ Total empirical score (total score assessed by the validator)

TSh $=$ Total expected score (maximum number of scores)

In the analysis of the effectiveness of the worksheets, it is seen from the test scores of student learning outcomes. Students' learning completeness can be calculated using the equation proposed by (Trianto, 2011) as follows:

Information:

$$
\mathrm{KB}=\frac{\mathrm{T}}{\mathrm{Tt}} \times 100 \%
$$

$\mathrm{KB}=$ Percentage of learning completeness

$\mathrm{T}=$ Total score obtained by students

$\mathrm{Tt}=$ Total total score

According to (Trianto, 2011), the determination of student learning completeness is determined by the KKM of each school. The indicator of effectiveness is if as many as $\geq 72 \%$ of the students' scores are above the KKM. The improvement of students' creative thinking 
using the normalized gain test (g) proposed by Hake adapted from (Sundayana, 2015) as follows:

$$
\text { Gain Ternormalisasi }(\mathrm{g})=\frac{\text { skor posttest }- \text { skor pretest }}{\text { skor ideal-skor pretest }}
$$

\section{Results and Discussion Results}

The results of the analysis of research on the development of math worksheets with the SPLDV Calc application are divided into three stages, namely the stage of define, design, and develop. The define stage includes front end analysis, concept analysis, and learning objectives. The front end analysis contains problems in the field, namely the low ability of students to think creatively as indicated by the average value of daily tests far from the KKM, namely 66. The low value of learning outcomes (pretest) proves that students need the development of teaching materials in the form of worksheets according to their field of expertise . Based on the concept analysis, it was found that students often made mistakes in identifying story problems, using SPLDV basic concepts and solving problems with several different solving methods. The results of the concept analysis are used by researchers as a reference for the preparation of the worksheets developed. In the analysis of learning objectives, it can be seen that the material to be displayed, the question grid in the worksheets developed, as a basis for the preparation of learning outcomes tests and the design of learning devices so that the desired learning objectives are achieved.

The second stage in this research is the design stage, the results obtained at the design stage are math worksheets using the SPLDV Calc application. The worksheet is shown in Figure 1.

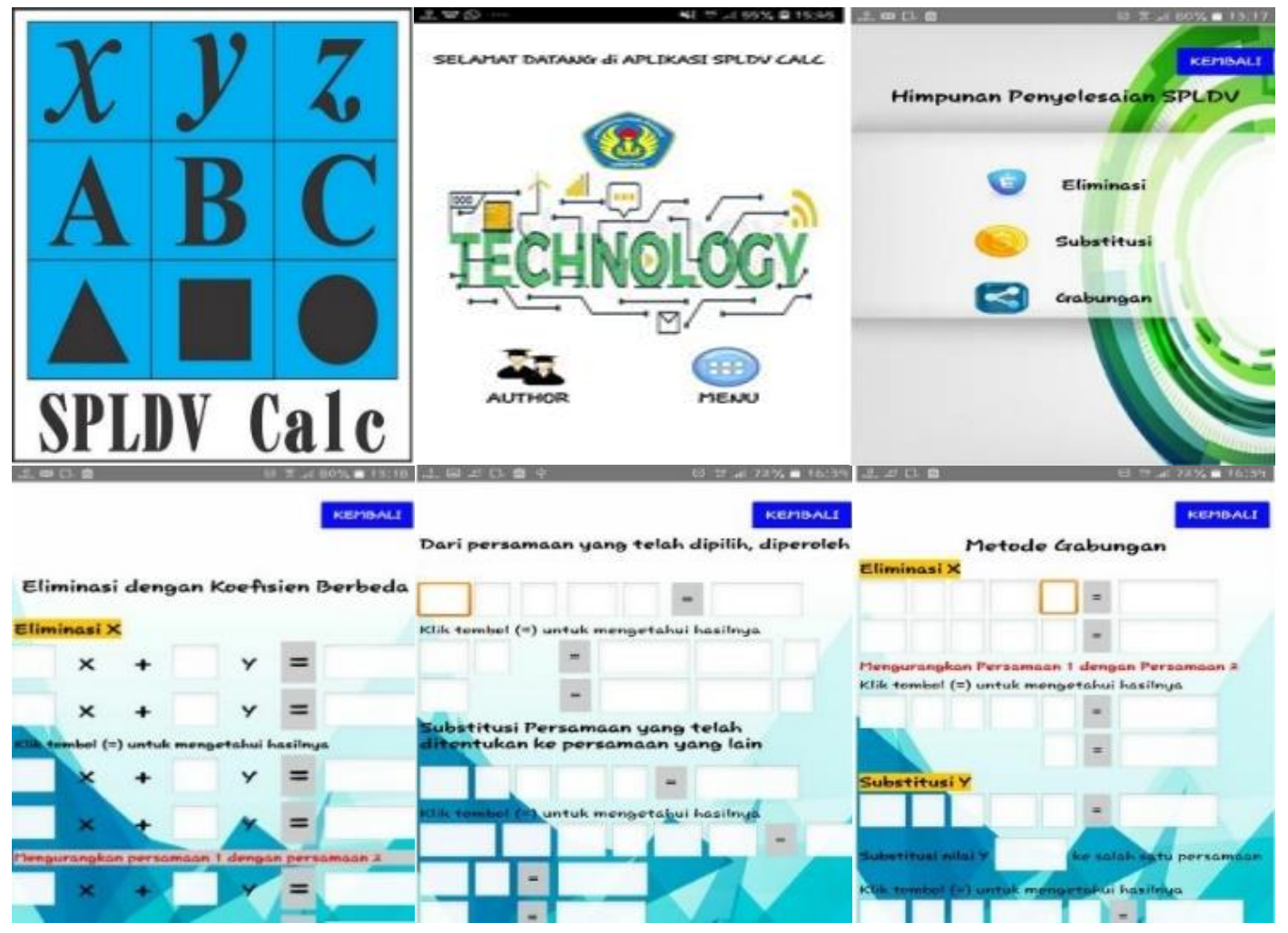

Figure 1. The SPLDV Calc application

At the develop stage, the activity carried out is the validation of the product being developed. The substance of the LKS validation refers to several assessment components from (Ahmadi \& Amri, 2014) and the assessment aspects of the SPLDV Calc application media adapted from (Akbar, 2013). The results of the validation analysis shown in Table 1. 
Table 1. Results of the LKS Validation

\begin{tabular}{|c|c|c|c|c|c|}
\hline \multirow[b]{2}{*}{ No } & \multirow{2}{*}{ Assessment Components } & \multicolumn{3}{|c|}{ Validator } & \multirow{2}{*}{$\begin{array}{c}\text { Average Percentage of } \\
\text { Components }\end{array}$} \\
\hline & & 1 & 2 & 3 & \\
\hline 1. & Content eligibility & $88 \%$ & $96 \%$ & $84 \%$ & $89 \%$ \\
\hline 2. & Language & $87 \%$ & $87 \%$ & $93 \%$ & $89 \%$ \\
\hline 3. & Serving & $88 \%$ & $80 \%$ & $88 \%$ & $85 \%$ \\
\hline 4. & Graphics & $85 \%$ & $85 \%$ & $90 \%$ & $87 \%$ \\
\hline \multicolumn{2}{|c|}{ Total Empirical Score (TSe) } & 74 & 74 & 75 & \\
\hline \multirow{3}{*}{\multicolumn{2}{|c|}{$\begin{array}{l}\text { Total Expectation Score (TSh) } \\
\text { Percentage of Validity (V) } \\
\text { Combined Percentage }\end{array}$}} & 85 & 85 & 85 & \\
\hline & & $87 \%$ & $87 \%$ & $88 \%$ & \\
\hline & & & $87 \%$ & & \\
\hline
\end{tabular}

Based on Table 1, the average percentage of validation results for each component is $89 \%$ for the content eligibility component, $89 \%$ for language, $85 \%$ for presentation, and $87 \%$ for graphic with a final percentage of $87 \%$. Analysis of the validity results in table 1 proves that the worksheets developed are very valid, or can be used without revision according to the validity criteria proposed by Akbar (2013) if the percentage of combined validity is in the interval $85.01 \%-100 \%$. The results of the SPLDV Calc application validation are shown in Table 2.

Table 2. Validation Results of the SPLDV Calc Application

\begin{tabular}{llcccc}
\hline \multirow{2}{*}{ No } & Assessment Aspects & \multicolumn{3}{c}{ Validator } & Average Percentage \\
\cline { 2 - 4 } of Aspects
\end{tabular}

Table 2 shows the results of the validity of the SPLDV Calc application which obtained an average percentage of $89 \%$ for the construct aspect, $89 \%$ for the content, and $89 \%$ for the language with the final percentage of the three validators of $89 \%$ with a validity level that is very valid, or can be used without revision.

\section{Discussion}

One of the ways to think creatively in students is by using the development of Student Worksheets (LKS) (Krisdiana, et al, 2019). The lack of suitability of student teaching materials in the form of student worksheets with their fields of expertise results in teachers often repeating material and allowing students to be less able to improve creative thinking skills. The worksheets contain short material and questions that must be done by students, although student worksheets can contribute to student learning but they still look less effective based on the low level of student activity and have not shown their creative thinking skills (Elfiani, 2017; Putri, 2015). This underlies researchers to develop math worksheets with the SPLDV Calc application, where students only obtain material theoretically during learning, thus making students less interested in understanding the material as a whole in line with the development of the automotive world.

The feasibility of teaching materials developed is viewed from three aspects, namely the content aspect with a percentage of $84 \%$, the presentation aspect of $85.22 \%$, and the language aspect of $77.18 \%$ with an average of $83.57 \%$ with appropriate criteria (Pangesti \& Yulianti, 2017). This is supported by the results of research by (Rahayu \& Imran, 2017) which state that the worksheets developed meet the validity criteria with a mean score of 4 on content 
appropriateness, an average of 4 in presentation, an average of 4 in language, and an average of 4 in graphic. with a decent category. The existence of alignment in the content feasibility component or content aspect, language or language aspects, presentation or presentation and graphic aspects, the worksheets with the SPLDV Calc application are feasible to be tested in limited or field trials.

The results of student learning completeness during learning using LKS showed that $91 \%$ of the 6 students in the limited trial above the KKM with 5 students experienced completeness while 1 student did not complete. While the average N-Gain score of 0.86 with a high level of interpretation proves that math worksheets can improve students' creative thinking skills based on indicators of creative thinking, namely fluency, flexibility, and novelty.

The increase in learning outcomes after using math worksheets with the SPLDV calc application through posttest questions obtained a percentage of learning completeness of $86 \%$ for 24 students with 21 students experiencing completeness while 3 students did not complete, so that they meet the effectiveness criteria because the field trial students have met the completeness of learning outcomes fulfilling KKM $\geq 72 \%$ (Trianto, 2011). This research is strengthened by the results of research conducted by (Wijayanti, 2014) regarding the development of student worksheets to improve students' creative thinking skills where classical completeness of the pretest and posttest student learning outcomes has increased. Another study conducted by (Pangesti \& Yulianti, 2017) states that learning using STEM-based teaching materials has a high level of effectiveness as shown by the results of 29 students' completeness in field trials of $82.76 \%$.

Students' creative thinking abilities in this study are in accordance with research conducted by (Krisdiana, et al., 2019) that students experienced an increase in creative thinking skills before and after using research-based learning by $87 \%$ with an average $\mathrm{N}$-Gain of 0.41 in the medium category and average ability. -the mean of creative thinking after using research-based learning increased from $\leq 55$ to 73.33 . Because research-based learning combines theoretical experience in the classroom and direct experience in everyday life and can build problems at hand.

One of the ways to think creatively in students is by using the development of Student Worksheets (LKS) (Krisdiana, et al, 2019). The lack of suitability of student teaching materials in the form of student worksheets with their fields of expertise results in teachers often repeating material and allowing students to be less able to improve creative thinking skills. The worksheets contain short material and questions that must be done by students, although student worksheets can contribute to student learning but they still look less effective based on the low level of student activity and have not shown their creative thinking skills (Elfiani, 2017; Putri, 2015). This underlies researchers to develop math worksheets with the SPLDV Calc application, where students only obtain material theoretically during learning, thus making students less interested in understanding the material as a whole in line with the development of the automotive world.

The use of suitable teaching materials in the form of worksheets aims to make students more competent. LKS is teaching material in the form of sheets containing assignments that students must do with the aim of activating students during the activity process, helping students develop concepts, training students to find and develop process skills (Lestari \& Yudhanegara, 2015). As a complement / means of supporting the implementation of the Learning Plans, LKS aims to lead students to produce original works (original) and promote student involvement in learning as expressed by (Majid \& Rochman, 2014). The worksheets used by students so far are still conventional in the form of books containing material summaries and practice questions that have not applied ICT. Even though the use of student worksheets has a positive impact on users, including improving students 'reasoning abilities according to (Fitriani et al, 2017) and can improve students' critical thinking skills (Lestari \& Darsono, 2018). With the LKS developed using the SPLDV Calc application, it is hoped that students will understand the concept, be able to solve problems related to natural phenomena, and improve creative, innovative thinking and be able to correlate various STEM disciplines with real problems. 
STEM education is an approach in science, technology, engineering and mathematics education integrated with an educational process that focuses on problem solving and is able to develop products, processes and systems in real life and everyday life (Devi et al, 2018). The learning model used is Project Based Learning (PjBL) STEM Laboy Rush which is a model to be implemented in the 2013 curriculum by emphasizing four scientific fields (Devi et al, 2018). Integrated STEM learning has the potential to prepare a competitive future workforce with 21 st-century skills, with creative thinking that can help students gain in-depth knowledge of the topics they are studying (Marsono \& Khasanah, 2019).

\section{Conclusion}

Based on the results of the research, it can be concluded that the mathematics worksheets with the SPLDV Calc application are suitable for use by teachers and students to assist the learning process of mathematics, this is indicated by (1) validity results of $87 \%$, (2) practicality results with a percentage of student response questionnaires of $85 \%$ gave a positive response (3) The result of the effectiveness of $86 \%$ was obtained from the posttest score (3) The $\mathrm{N}$-Gain score in the field trial was 0.73 with high interpretation so that it could improve students' creative thinking skills. The research findings show that students prefer to learn using android because difficult questions can be solved quickly and more effectively.

\section{References}

Ahmadi, I. K., \& Amri, S. (2014). Pengembangan \& Model Pembelajaran Tematik Integratif. PT Prestasi Pustakaraya.

Akbar, S. (2013). Instrumen Perangkat Pembelajaran. PT Remaja Rosdakarya.

Creswell, W. J. (2012). Educational Research: Planning, Conducting and Evaluating Quantitative and Qualitative Research. Pearson.

Devi, P. K., Herliani, E., Setiawan, R., Yanuar, Y., \& Karyana, S. (2018). Materi IHT Instruktur Pelatihan Pembelajaran Berbasis STEM. PPPPTK VEDC Malang.

Elfiani, F. (2018). Upaya Meningkatkan Kemampuan Berpikir Kreatif Siswa Kelas Vii F Mts Ma'arif Nu 1 Wangon Melalui Pembelajaran Ideal Problem Solving. AlphaMath: Journal of Mathematics Education, 3(2), 27-35. http://jurnalnasional.ump.ac.id/index.php/alphamath/article/view/2752/2021

Erozkan, A. (2013). The effect of communication skills and interpersonal problem solving skills on social self-efficacy. Educational Sciences: Theory and Practice, 13(2), 739-745. https://eric.ed.gov/?id=EJ1017303

Farida, I., Liliasari, L., Widyantoro, D. H., \& Sopandi, W. (2009, October). The importance of development of representational competence in chemical problem solving using interactive multimedia. In Proceeding of The Third International Seminar on Science Education (pp. 259-277). Universitas Pendidikan Indonesia. https://www.researchgate.net/publication/308369015_The_Importance_of_Developm ent_of_Representational_Competence_in_Chemical_Problem_Solving_Using_Intera ctive_Multimedia

Fitriani, D., Kaniawati, I., \& Suwarma, I. R. (2017, October). Pengaruh Pembelajaran Berbasis STEM (Science, Technology, Engineering, And Mathematics) Pada Konsep Tekanan Hidrostatis Terhadap Causal Reasoning Siswa SMP. In Prosiding Seminar Nasional Fisika (E-Journal) (Vol. 6, pp. https://doi.org/10.21009/03.SNF2017.01.EER.08

Krisdiana, I., Masfingatin, T., Murtafiah, W., \& Widodo, S. A. (2019, March). Research-based learning to increase creative thinking skill in mathematical Statistic. In Journal of Physics: Conference Series (Vol. 1188, No. 1, p. 012042). IOP Publishing. https://iopscience.iop.org/article/10.1088/1742-6596/1188/1/012042/meta

Krisdiana, I., Masfingatin, T., Murtafiah, W., \& Widodo, S. A. (2019, November). WorksheetBased Learning Research to Improve Creative Thinking Skills. In Journal of Physics: Conference Series (Vol. 1254, No. 1, p. 012054). IOP Publishing. https://doi.org/10.1088/1742-6596/1254/1/012054

Lestari, D. A. B., Astuti, B., \& Darsono, T. (2018). Implementasi LKS Dengan Pendekatan 
STEM (Science, Technology, Engineering, And Mathematics) Untuk Meningkatkan Kemampuan Berpikir Kritis Siswa. Jurnal Pendidikan Fisika dan Teknologi, 4(2), 202207. http://dx.doi.org/10.29303/jpft.v4i2.809

Lestari, K., \& Yudhanegara., M. (2015). Penelitian Pendidikan Matematika. Refika Aditama.

Majid, A., \& Rochman, C. (2014). Pendekatan IImiah dalam Implementasi Kurikulum 2013. PT Remaja Rosdakarya.

Marsono, M., Khasanah, F., \& Yoto, Y. (2019, January). Integrating STEM (Science Technology Engineering and Mathematics) Education on Advancing Vocational Student's Creative Thinking Skills. In 2nd International Conference on Vocational Education and Training (ICOVET 2018) (pp. 170-173). Atlantis Press. https://dx.doi.org/10.2991/icovet-18.2019.43

Mulyatiningsih, E. (2013). Metode Penelitian Terapan Bidang Pendidikan. Alfabeta.

Munandar. (2012). Pengembangan Kreativitas Anak Berbakat. Rineka Cipta.

Murti, K. E. (2015). Pendidikan Abad 21 dan Aplikasinya dalam Pembelajaran di SMK. Pusat Pengembangan dan Pemberdayaan Pendidik dan Tenaga Kependidikan Seni dan Budaya Yogyakarta.

Pangesti, K. I., Yulianti, D., \& Sugianto, S. (2017). Bahan ajar berbasis STEM (Science, Technology, Engineering, and Mathematics) untuk meningkatkan penguasaan konsep siswa SMA. UPEJ Unnes Physics Education Journal, 6(3), 53-58. https://doi.org/10.15294/upej.v6i3.19270

Putri, D. (2015). Pengembangan Lembar Kerja Siswa Berbasis Mind Mapping Pada Materi Laju Reaksi Untuk Melatihkan Keterampilan Berfikir Kreatif Siswa Kelas XI SMA (Development Of Students Worksheet Based On Mind Mapping Inreaction Rates Material To Practice Students Creative Thinking Skills For Senior High School Grade $\mathrm{XI}$. UNESA Journal of Chemical Education, 4(2). https://jurnalmahasiswa.unesa.ac.id/index.php/journal-of-chemicaleducation/article/view/11964

Rahayu, E., \& Imran, A. (2017). Pengembangan Lembar Kerja Siswa (LKS) Berorientasi Pembelajaran Inkuiri untuk Meningkatkan Keterampilan Berpikir Kreatif Siswa. Jurnal IImiah Mandala Education, 3(1), 403-410. http://dx.doi.org/10.36312/jime.v3i1.134

Sani, R. A., Manurung, S. R., \& S. (2018). Penelitian Pendidikan. Tira Smart.

Siswono, T. Y. (2005). Upaya meningkatkan kemampuan berpikir kreatif siswa melalui pengajuan masalah. Jurnal Pendidikan Matematika dan Sains, 10(1), 1-9. https://www.academia.edu/download/31423532/paper05_problemposing.pdf

Siswono, T. Y. (2018). Pembelajaran Matematika Berbasis Pengajuan dan Pemecahan Masalah. PT Remaja Rosdakarya.

Sukmadinata, N. S. (2015). Metode Penelitian Pendidikan. PT Remaja Rosdakarya.

Sundayana, R. (2015). Statistika Penelitian Pendidikan. Alfabeta.

Trianto. (2011). Mendesain Model Pembelajaran Inovatif-Progresif. Kencana Prenada Media Group.

Wang, Y., \& Chiew, V. (2010). On the cognitive process of human problem solving. Cognitive systems research, 11(1), 81-92. https://doi.org/10.1016/j.cogsys.2008.08.003

Widodo, S. A. (2017). Development of Teaching Materials Algebraic Equation To Improve Problem Solving. Infinity Journal, 6(1), 59. https://doi.org/10.22460/infinity.v6i1.239

Widodo, S. A., Prahmana, R. C. I., Purnami, A. S., \& Turmudi. (2018). Teaching materials of algebraic equation. Journal of Physics: Conference Series, 943(1). https://doi.org/10.1088/1742-6596/943/1/012017

Widoyoko, E. P. (2013). Teknik Penyusunan Instrumen Penelitian. Pustaka Pelajar.

Wijayanti, F. (2014). Pengembangan LKS IPA Berbasis Multiple Intelligences pada Tema Energi dan Kesehatan untuk Meningkatkan Kemampuan Berpikir Kreatif Siswa. Universitas Negeri Semarang.

Yektyastuti, R., \& Ikhsan, J. (2016). Pengembangan Media Pembelajaran Berbasis Android Pada Materi Kelarutan Untuk Meningkatkan Performa Akademik Siswa SMA. Jurnal Inovasi Pendidikan IPA, 2(1), 88-99. https://doi.org/10.21831/jipi.v2i1.10289 